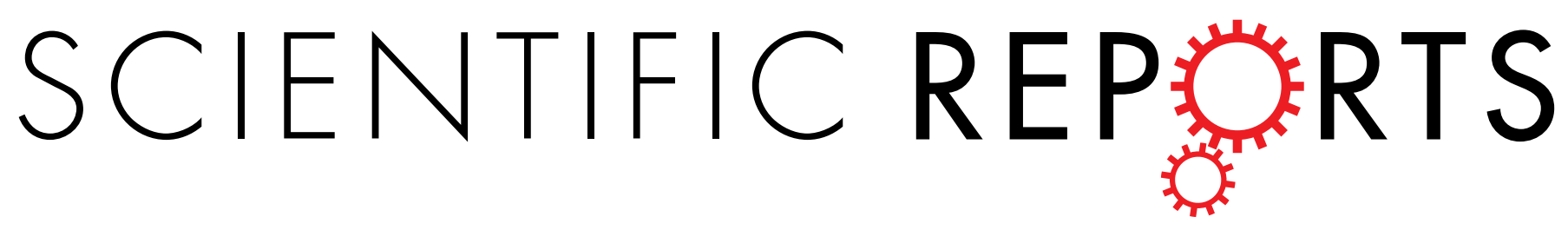

\title{
OPEN Author Correction: Isothermal Amplification of Long, Discrete DNA Fragments Facilitated by Single-Stranded Binding Protein
}

Yinhua Zhang \& Nathan A. Tanner

Correction to: Scientific Reports https://doi.org/10.1038/s41598-017-09063-x, published online 17 August 2017

This Article contains an error in Figure 3, where the gel image is formatted incorrectly. The correct Figure 3 appears below as Figure 1.

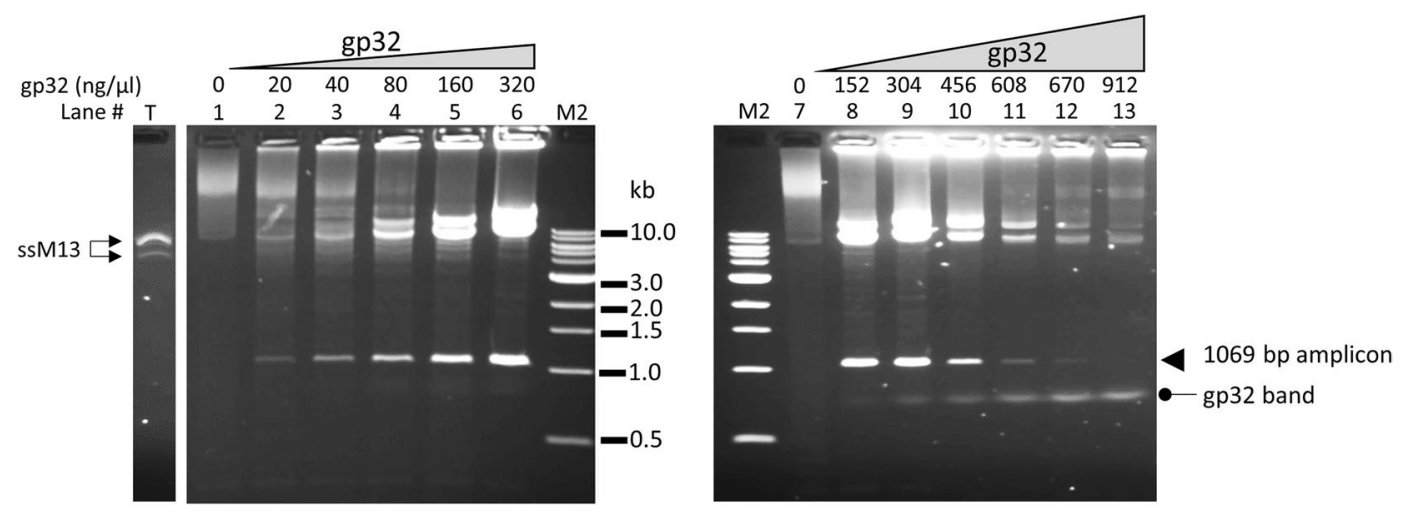

Figure 1. T4 gp32 protein-assisted isothermal amplification on circular ssDNA M13. Lane T was loaded with $0.1 \mu \mathrm{g}$ ss M13 DNA alone without any treatment. The amplification of $0.1 \mu \mathrm{g}$ of M13 ssDNA using primer \# 25 with low range of gp32 (20-320 ng/ $\mu$ l) (left panel, lanes 2-6), or high range of gp32 (152-912 ng/ $\mu$ l) (right panel, lanes 8-13). Each panel has a lane with no gp32 (Lanes 1 and 7) as negative controls. The band of the single amplicon (1069 bp) is marked by an arrow in the right panel. M2 is $1 \mathrm{~kb}$ ladder DNA markers.

(i) Open Access This article is licensed under a Creative Commons Attribution 4.0 International License, which permits use, sharing, adaptation, distribution and reproduction in any medium or format, as long as you give appropriate credit to the original author(s) and the source, provide a link to the Creative Commons license, and indicate if changes were made. The images or other third party material in this article are included in the article's Creative Commons license, unless indicated otherwise in a credit line to the material. If material is not included in the article's Creative Commons license and your intended use is not permitted by statutory regulation or exceeds the permitted use, you will need to obtain permission directly from the copyright holder. To view a copy of this license, visit http://creativecommons.org/licenses/by/4.0/.

(c) The Author(s) 2018 